\title{
PENTINGNYA PERENCANAAN DAN IMPLEMENTASI KEPERAWATAN TERHADAP KEPUASAN PASIEN DI RUMAH SAKIT \\ Friderikus Zebua \\ zebuafriderikus@gmail.com
}

\section{LATAR BELAKANG}

Perencanaan Keperawatan Merupakan suatu proses penyusunan berbagai intervensi keperawatan yang dibutuhkan untuk mencegah, menurunkan, atau mengurangi masalah-masalah klien. Perencanaan ini merupakan langkah ketiga dalam membuat suatu proses keperawatan. Langkah dalam tahap perencanaan ini dilakukan setelah menentukan tujuan dan kriteria hasil yang diharapkan dengan menentukan rencana tindakan apa yang akan dilaksanakan dalam mengatasi masalah klien.

Dalam membuat rencana tindakan perawat harus mengetahui juga tentang instruksi atau perintah tentang tindakan keperawatan apa yang akan dilakukan dari perawat primer (pembuat asuhan keperawatan primer). Untuk memudahkan dalam menentukan rencana tindakan, maka ada beberapa persyaratan dalam menuliskan rencana tindakan diantaranya harus terdapat unsur tanggal, kata kerja yang dapat diukur yang dapat dilihat, dirasa dan didengar, adanya subjek, hasil, target tanggal dan tanda tangan perawat.

Implementasi keperawatan adalah serangkaian kegiatan yang dilakukan oleh perawat untuk membantu klien dari masalah status kesehatan yang dihadapi ke status kesehatan yang baik yang menggambarkan kriteria hasil yang diharapkan. Ukuran intervensi keperawatan yang diberikan kepada klien terkait dengan dukungan dan pengobatan dan tindakan untuk memperbaiki kondisi dan pendidikan untuk klien keluarga atau tindakan untuk mencegah masalah kesehatan yang muncul dikemudian hari. Proses pelaksanaan implementasi harus berpusat kepada kebutuhan klien dan faktor-faktor lain yang mempengaruhi kebutuhan keperawatan\& strategi implementasi keperawatan\& dan kegiatan komunikasi.

Implementasi keperawatan adalah kegiatan mengkoordinasikan aktivitas pasien, keluarga, dan anggota tim kesehatan lain untuk mengawasi dan mencatat respon pasien terhadap tindakan keperawatan yang telah dilakukan (Nettina, 2002). Jadi, implemetasi keperawatan adalah 
kategori serangkaian perilaku perawat yang berkoordinasi dengan pasien, keluarga, dan anggota tim kesehatan lain untuk membantu masalah kesehatan pasien yang sesuai dengan perencanaan dan kriteria hasil yang telah ditentukan dengan cara mengawasi dan mencatat respon pasien terhadap tindakan keperawatan yang telah dilakukan.

\section{METODE}

Jurnal ini menggunakan metode tersearch dan analisis dari berbagai sumber seperti buku teks, buku referensi jurnal, ebook, dan juga membandingkan beberapa jurnal yang berhubungan dengan tujuan dan kriteria perencanaan asuhan keperawatan di rumah sakit. Dari analisi berbagai sumber digunakan Untuk mengetahui pengaruh perencanaan dan implementasi keperawatan di rumah sakit. Jurnal yang saya ambil adalah jurnal yg di terbitkan 10 tahun terakhir.

\section{HASIL}

Penelitian ini menunjukkan perencanaan dan implementasi juga belum mencapai standar yang ditetapkan Depkes RI. Implementasi merupakan tindakan atau aplikasi dari rencana asuhan keperawatan untuk mencapai tujuan yang diharapkan. Dalam melakukan tindakan sesuai dengan rencana keperawatan maka diperlukan jumlah tenaga perawat yang cukup, pengetahuan dan keterampilan yang baik. Tenaga perawat yang paling dibutuhkan ketika jumlah klien meningkat dan kondisi klien menurun (Potter \& Perry, 2005).

Hal ini merupakan komponen manajemen keperawatan yang perlu diperhatikan oleh manajer keperawatan (Gillies, 2005). Hal ini kembali kepada peran manajer perawat untuk memperhatikan jumlah tenaga kerja atau perawat agar sebanding dengan beban kerja perawat, pengetahuan dan kemampuan perawat perawat juga ditingkatkan melalui pelatihan dan pendidikan lanjut.

Tujuan rencana asuhan keperawatan yaitu tujuan administrasi meliputi mengidentifikasi fokus keperawatan individu atau keluarga, membedakan tanggung jawab perawat dengan profesi kesehatan lainnya, menyusun kriteria guna pengulangan asuhan keperawatan dan evaluasi, keberhasilan asuhan keperawatan, menyediakan kriteria klasifikasi klien, sedangkan tujuan klinik meliputi suatu pedoman dalam penulisan, mengkomunikasikan asuhan keperawatan yang akan diimplememtasikan dengan perawat lain seperti apa yang akan diajarkan, apa yang harus 
diobservasi, apa yang akan dilakukan. Menyusun kriteria hasil (outcome) guna pengulangan asuhan keperawatan dan evaluasi keberhasilan asuhan keperawatan, rencana intervensi yang spesifik dan langsung bagi perawat untuk melaksanakan intervensi kepada klien dan keluarganya (Cafenito,2006).

\section{PEMBAHASAN}

Perencanaan merupakan suatu petunjuk tertulis yang menggambarkan secara tepat rencana tindakan keperawatan yang dilakukan terhadap klien sesuai dengan kebutuhannya berdasarkan diagnosis keperawatan. Rencana asuhan keperawatan adalah petunjuk tertulis yang menggambarkan secara tepat mengenai rencana tindakan yang dilakukan terhadap klien sesuai dengan kebutuhannya berdasarkan diagnosis keperawatan. Pada saat implementasi perawat harus melaksanakan hasil dari rencana keperawatan yang di lihat dari diagnosa keperawatan. Pada saat implementasi perawat harus melaksanakan hasil dari rencana keperawatan yang di lihat dari diagnosa eperawatan. Di mana perawat membantu klien dari masalah status kesehatan yang dihadapi kestatus kesehatan yang lebih baik yang menggambarkan kriteria hasil yang diharapkan.

Implementasi keperawatan adalah serangkaian kegiatan yang dilakukan oleh perawat untuk membantu klien dari masalah status kesehatan yang dihadapi kestatus kesehatan yang lebih baik yang menggambarkan kriteria hasil yang diharapkan. Implementasi merupakan inisiatif dari rencana tindakan untuk mencapai tujuan yang spesifik. Tahap pelaksanaan dimulai setelah rencana tindakan disusun dan ditujukan pada nursing orders untuk membantu klien mencapai tujuan yang diharapkan.

\section{Tujuan Rencana Asuhan Keperawatan}

\section{Tujuan umum:}

1. Sebagai alat komunikasi antara sesama anggota perawatan danantar tim kesehatan lainnya

2. Untuk meningkatkan kesinambungan asuhan keperawatan terhadap klien.

3. Mendokumentasikan proses dan kriteria hasil asuhan keperawatan yang akan dicapai.

\section{Tujuan Administratif :}


1. Mengidentifikasi fokus keperawatan kepada klien atau kelompok

2. Membedakan tanggung jawab perawat dengan profesi kesehatan lainnya

3. Menyediakan suatu kriteria guna pengulangan dan evaluasi keperawatan

4. Menyediakan kriteria klasifikasi klien.

Tujuan kilen dan tujuan keperawatan adalah standar atau ukuran yang digunakan untuk mengevaluasi kemajuan klien atau keterampilan perawat. Menurut Alfaro(1994), tujuan klien merupakan pernyataan yang menjelaskan suatu perilaku klien, keluarga, atau kelompok yang dapat diukur setelah intervensi keperawatan diberikan.

Tipe implementasi keperawatan Secara garis besar terdapat tiga kategori dari implementasi keperawatan (Craven dan Hirnle, 2000) antara lain:

a. Cognitive implementations yaitu Meliputi pengajaran atau pendidikan, menghubungkan tingkat pengetahuan klien dengan kegiatan hidup sehari-hari, membuat strategi untuk klien.dengan disfungsi komunikasi, memberikan umpan balik, mengawasi tim keperawatan, mengawasi penampilan klien dan keluarga, serta menciptakan lingkungan sesuai kebutuhan, dan lain lain.

b. Interpersonal implementations yaitu Meliputi koordinasi kegiatan-kegiatan, meningkatkan pelayanan, menciptakan komunikasi terapeutik, menetapkan jadwal personal, pengungkapan perasaan, memberikan dukungan spiritual, bertindak sebagai advokasi klien, role model, dan lain lain.

c. Technical implementations yaitu Meliputi pemberian perawatan kebersihan kulit, melakukan aktivitas rutin keperawatan, menemukan perubahan dari data dasar klien, mengorganisir respon klien yang abnormal, melakukan tindakan keperawatan mandiri, kolaborasi, dan rujukan, dan lain-lain. 
Karakteristik rencana tindakan keperawatan:

a. Konsisten dengan rencana tindakan.

b. Berdasarkan prinsip-prinsip ilmiah(rasional).

c. Berdasarkan situasi individu klien.

d. Digunakan untuk menciptakan suatu situasi yang aman dan teraupetik.

e. Menciptakan suatu situasi pengajaran.

f. Menunggu saran yang sesuai(ANA,1973).

Perencanaan keperawatan disusunberdasarkan diagnosa keperawatan yang meliputi beberapa point seperti :

- Prioritas asuhan keperawatan dengan kriteria : Spesifik, bisadiukur, bisa dicapai,realistik, adabatas waktu.

- Tujuan asuhan keperawatandengan kriteria : spesifik, bisa diukur, bisa dicapai,realistik, ada batas waktu.

- Rencana tindakan dengan kriteria yang disusun berdasarkan tujuan asuhan keperawatan, melibatkanpaien/keluarga,mempertimbangkan latar belakang budaya pasien/keluarga,menentukan alternative tindakan yang tepat, mempertimbangkan kebijaksaandan peraturan yang ber laku, lingkungan, sumberdaya, dan fasilitas yang ada, menjamin rasa aman dan nyaman bagi pasien, kalimat intruksi, ringkas, tegas dengan bahasanya mudahdimengerti

Ada tiga prinsip pedoman implementasi keperawatan (Haryanto,2007), yaitu :

a. Mempertahankan keamanan klien dengan Keamanan merupakan focus utama dalam melakukan tindakan. Oleh karena, tindakan yang membahayakan tidak hanya dianggap sebagai pelanggaran etika standar keperawatan professional, tetapi juga merupakan suatu tindakan pelanggaran hukum yang dapat ditutut.

b. Memberikan asuhan yang efektif dengan memberikan asuhan yang efektif adalah memberiakan asuhan sesuai dengan yang harus dilakukan semakin baik pengetahuan dan pengalaman seorang perawat, maka semakin efektif asuhan yang diberikan. 
c. Memberikan asuhan seefisien mungkin dengan memberikan asuhan yang efisien berarti perawat dalam memberikan asuhan dapat mengunakan waktu sebaik mungkin sehingga dapat menyelesaikan masalah kilen.

\section{Tahap - Tahap Implementasi}

1. Tahap I: Persiapan merupakan tahap awal tindakan keperawatan ini menuntut perawat mempersiapkan segala sesuatu yang diperlukan dalam tindakan. Meliputi : Review tindakan keperawatan yang diidentifikasi pada tahap perencanaan, menganalisa pengetahuan dan ketrampilan keperawatan yang diperlukan, mengetahui komplikasi dari tindakan keperawatan yang mungkin timbul, menentukan dan mempersiapkan peralatan yang diperlukan, mempersiapkan lingkungan yang kondusif sesuai dengan tindakan, dan mengidentifikasi aspek hukum dan etik terhadap resiko dari potensi tindakan.

2. Tahap II: Intervensi merupakan tahap yang berfokus pada pelaksanaan tindakan perawatan adalah kegiatan pelaksanaan tindakan dari perencanaan untuk memenuhi kebutuhan fisik dan emosional. Pendekatan ini meliputi: Independen adalah suatu kegiatan yang dilaksanakan oleh perawat tanpa petunjuk dan perintah dari dokter atau tenaga kesehatan lainnya. Tipe tindakan independen keperawatan dapat dikatagorikan menjadi 4, yaitu tindakan diagnostik, tindakan terapeutik, tindakan edukatif, dan tindakan merujuk, interdependen menjelaskan suatu kegiatan yang memelukan suatu kerjasama dengan tenaga kesehatan lainnya,misalnya tenaga sosial, ahli gizi, fisioterapi dan dokter, dan dependen ini berhubungan dengan pelaksanaan rencana tindakan medis. Tindakan tersebut menandakan suatu cara dimana tindakan medis dilaksanakan.

3. Tahap III: Dokumentasi merupakan pelaksanaan tindakan keperawatan harus diikuti oleh pencatatan yang lengkap dan akurat terhadap suatu kejadian dalam proses keperawatan. 


\section{PENUTUP}

Perencanaan adalah merupakan bagian dari fase pengorganisasian dalam proses keperawatan sebagai pedoman untuk mengarahkan tindakan keperawatan dalam usaha membantu, meringankan, memecahkan masalah atau untuk memenuhi kebutuhan klien. Suatu perencanaan yang tertulis dengan baik akan memberi petunjuk dan arti pada asuhan keperawatan karena perencanaan adalah sumber informasi bagi semua yang terlibat dalam asuhan keperawatan klien.

Implemetasi keperawatan adalah kategori serangkaian perilaku perawat yang berkoordinasi dengan pasien, keluarga, dan anggota tim kesehatan lain untuk membantu masalah kesehatan pasien yang sesuai dengan perencanaan dan kriteria hasil yang telah ditentukan dengan cara mengawasi dan mencatat respon pasien terhadap tindakan keperawatan yang telah dilakukan. implementasi pelaksanaan kegiatan dibagi dalam beberapa kriteria yaitu: Dependen Interventions: dilaksanakan dengan mengikuti order dari pemberi perawatan kesehatan lain, Collaborative (interdependen): interpensi yang dilaksanakan dengan professional kesehatan lainnya, dan Independent (autonomous) Intervention: intervensi dilakukan dengan melakukan nursing orders dan sering juga digabungkan dengan order dari medis.

\section{DAFTAR PUSTAKA}

Asmuji. 2012. Manajemen Keperawatan Konsep dan Aplikasi. Jogjakarta: Ar-Ruzz Media.

Bausat, N. (2016). Strategi RSUD Tenriawaru Kabupaten Bone menuju implementasi sistem pembayaran prospektif. Jurnal Administrasi Rumah Sakit Indonesia, 1(2).

Butar-Butar, J., \& Simamora, R. H. (2016). Hubungan Mutu Pelayanan Keperawatan dengan Tingkat Kepuasan Pasien Rawat Inap di RSUD Pandan Kabupaten Tapanuli Tengah. Jurnal Ners Indonesia, 6(1), 50-63.

Efendi, N. F. (2015). Pendidikan dalam keperawatan. Surabaya: Salemba Medika 
Kemenkes RI. (2015). Profil Kesehatan Indonesia Tahun 2014. Jakarta

Khamida, K., \& Mastiah, M. (2015). Kinerja Perawat Dalam Memberikan Asuhan Keperawatan Berpengaruh Terhadap Kepuasan Pasien Rawat Inap. Journal of Health Sciences, 8(2). Potter, P. A., \& Perry, A. G., (2013). Fundamentals of nursing. (8th ed). Elsevier.

Potter, A., \& Perry, A. (2017). Buku Ajar Fundamental Keperawatan: Konsep, Proses, dan Praktik (4th ed.). Jakarta: Buku Kedokteran EGC.

Rosdahl, C. B., \& Kowalski, M. T. (2014). Buku Ajar Keperawatan Dasar. Jakarta: EGC

Sari, I. P. (2016). Hubungan Pengetahuan Perawat Tentang Model Asuhan Keperawatan Metode Tim Dengan Implementasinya Di Ruang Bedah Flamboyan Rsud Dr Soetomo Surabaya. Medica Majapahit, 8(2), 74-79

Simamora, R. H. (2005). Hubungan Persepsi Perawat Pelaksana Terhadap Penerapan Fungsi Pengorganisasian Yang Dilakukan Oleh Kepala Ruangan Dengan Kinerjanya Diruang Rawat Inap RSUD Koja Jakarta Utara (Doctoral dissertation, Tesis FIK UI, Tidak dipublikasikan).

Syafrini, R. O., Keliat, B. A., \& Putri, Y. S. E. (2015). Efektivitas Implementasi Asuhan Keperawatan Isolasi Sosial Dalam Mpkp Jiwa Terhadap Kemampuan Klien. Jurnal Ners, 10(1), 175-182. 